\title{
Foreign Direct Investment In Transition Economies: An Institutional Approach
}

\author{
Agim Kukeli, (Email: akukeli@mesastate.edu), Mesa State College
}

\begin{abstract}
Foreign direct investment ( $F D I^{I}$ thereafter) is very important for economic growth in transition economies. They have major impact in economic development as a source of physical capital, diffusion of technology, improvements in management and marketing techniques, and enhancing institutional setting of these economies toward market oriented. In this paper, an institutional approach to FDI inflow is investigated to identify relevant factors that have shaped and influenced transition economies. The role of institutions in the inflow of FDI in transition economies is estimated empirically by using Seemingly Unrelated Regression Estimation (SURE) technique.
\end{abstract}

\section{INTRODUCTION}

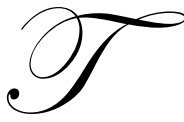

ransition economies in general have been one of the main fields of research for economists for the last 17 years. This is due to many questions that arise about the economic system as a whole and the uniqueness of such a great and unprecedented transformation. In this paper, an institutional approach to foreign direct investment inflow is investigated to identify relevant factors that have shaped and influenced transition economies.

The approach that has been proposed draws on institutionalists' theses asserting that underlying institutions in general drive economic activity. We take this idea and apply it to FDI inflow in transition economies. This is because these countries have undertaken great institutional transformation in their efforts to move their planned economies to market oriented economies. This approach to foreign direct investment flows will increase our understanding of both institutional impact and FDI inflow in these countries economies.

Conclusions drawn are that institutions, as the core part of an economic system in transformation, play a crucial role in the flow of FDI, which in turn facilitates and accelerates economic reform. These forces are dualistic in nature in the sense that some can be transformed fast but the embedded force will be a barrier for the change to have a full effect on the economy. The embedded institutions are those coming from the inherited tradition, culture, and informal interactions of agents in the market.

The econometric model proposed in this study is that of fixed effect panel data econometric analysis. A Seemingly Unrelated Regression Estimation (SURE) will be used to correct for heteroscedasticity and contemporaneous correlation (Dielman, 1989). This will allow capturing FDI variations in time and space and explain the variation on FDI by the variation of independent variables. A number of hypotheses are posited, methodology and data gathering are described, and econometric technique and results are discussed. The transition economies covered in this study are those of Central and Eastern Europe. We have shown that institutions (whether formal or informal and whether created or adopted) along with government policies (mode of transition and exchange rate regime for example) are very important forces that will attract FDI flow. The problem with

\footnotetext{
${ }^{1}$ FDI takes place when a firm acquires ownership control of a production unit in a foreign country. There are three basic forms of FDI: -establishing new branch, -acquiring control share of an existing firm, and -participating jointly in a domestic firm. World Bank defines FDI as follow: "Foreign direct investment is net inflows of investment to acquire a lasting management interest (10 percent or more of voting stock) in an enterprise operating in an economy other than that of the investor."
} 
institutions is that one would face very difficult job to measure them or their progress. This issue has been tentatively solved in our paper by employing data from Freedom House (Nation in Transit, 1998 and 2002).

\section{SURVEY OF EMPIRICAL STUDIES}

Empirical studies on the FDI inflows can be grouped into two categories: studies on FDI inflows and outflows in transition economies, and studies focused on the institutional aspects of FDI. The second group of studies has been done with reference to developing countries, like Latin American countries and other developing countries. The first group of studies is mostly country case studies (we focus on studies done with respect to transitional economies).

Fabry (2001), in "The role of inward-FDI in the transition countries in European analytical framework", has studied the different effects (roles) that FDI might have in a transition economy. She has divided these roles in two groups: FDI contribution with reference to modernization and an increase in efficiency, therefore reorienting the production process, and FDI impacts- absorption of FDI from host country, assimilation and diffusion of knowledge. By using Granger causality test, the author argues that FDI may help the transition economy up-grade, but FDI itself is not suited to replace industrial and technological changes for long-term growth.

Using firm-level data based on a worldwide survey of companies in 1995 and covering 25 transition economies, S. H. Zeghni (2001), shows that there is a positive relationship between countries' transformation progress and the probability of a country being chosen for FDI inflows. Applying a probit model the following factors are chosen to be as determinants of FDI in this study: GDP per capita (as an proxy for the size of the market), growth rate of GDP, transition progress, regional tension, entry cost index, WTO (World Trade Organization) membership and/or applicant, and telephone lines. His two major findings are: a positive relationship between countries progress in transforming the economy towards market and FDI attraction, and decrease in regional tension and FDI inflows.

Szanyi (2001) has studied different aspects, like Greenfield investment versus privatization and FDI evolution, of FDI in Hungarian economy during its unique transition from centralized economy to a free market. The author concludes, "The motivations of foreign investors are combined differently in privatization and Greenfield investments. Market seekers tend to participate more in privatization; resource seekers prefer Greenfield investments." In addition, he points out the importance of creating basic political and economic stability and a working institutional framework to increase the efficiency of FDI inflows. His analysis is more of a survey in nature and his conclusions are not backed by data.

Antaloczy and Sass (2001), using data, argue that Greenfield FDI is due to IFTZ's (industrial free trade zone) adding to the location component of Dunning's OLI thesis. IFTZ's were first introduced in 1982 with an objective of attracting export-oriented high technology FDI to Hungary.

Empirical studies on FDI inflows in transition economies have been limited due to the lack of data and short period of time in which countries have been undergoing major changes. These studies are more of a case study of a particular country than of a general study of a region. Institutional factors that influence the FDI have more often been theorized and hypothesized than tested.

Political stability and government policies have been recognized as factors that influence FDI flows along with others, like market imperfections, size of the market, and geography. Nigh (1986) studied two classes of political events (intra-nation, and inter-nation events) and their effect in the FDI decisions of US multinational firms to invest in Latin American countries.

He used a panel data analysis to examine the relationship between political events and FDI for two reasons: to increase the sample size and the reliability of estimates of the regression parameters. Data used are time series for 21 years (1954-1975) crossed over eight countries (Mexico, Panama, Columbia, Venezuela, Peru, Brazil, Chile, and 
Argentina). The conclusion of his study is that "investors assess political events in general rather than investmentspecific terms."

His approach uses political events to explain the variation on FDI flows. The expansion of this approach, by using a combination of institutional factor (political stability and civil liberties) and policy factor (trade index, inflation, and exchange rate control) as determinants of FDI flows would be more appropriate for transition economies. The focus will be studying the relationship between FDI and institutions that affect its flow in different countries, i.e., transition economies. In addition, there will be an empirical estimation of the effects of institutions and policies in FDI flows in these countries. An analysis of how institutional changes take place in these countries is proposed in this paper in order to provide the background for the relationship between institutions, policies (government), and FDI inflow.

\section{THE MODEL, DATA, AND HYPOTHESIS}

It has been shown that institutional reform and economic policies in transition economies is far more complicated than what the "Washington consensus" has suggested. It also can be stated that both affect the FDI inflow in transition economies. A model in which institutional reform and economic stabilization policies play a crucial role on the FDI inflow is presented. We will assume that the amount of FDI in a given country will be determined by two factors, the institutions to be developed (formal and informal institutions), and the countries' policy with respect to foreign investments. From the institutional progress point of view, the one that will most likely affect the level of FDI will be political stability (to be defined below), degree of privatization of state properties, and development and enforcement of private property rights (included in the civil liberties index). The policy factors that will affect inflows of FDI will be economic stability expressed in two measurements; controlling of inflation, and an exchange rate regime that a country adopts. Also, the level of openness will determine capital inflows.

The panel data (a combination of time series with cross sectional data) model will be used to study such effects. Symbolically the model we are using can be written in a log-log form as follow:

$\ln \left(\mathrm{Y}_{\mathrm{it}}\right)=\alpha_{\mathrm{i}}+\beta_{1} \ln \left(\mathrm{X}_{1 \mathrm{it}}\right)+\beta_{2} \ln \left(\mathrm{X}_{2 \mathrm{it}}\right)+\beta_{3} \ln \left(\mathrm{X}_{3 \mathrm{it}}\right)+\gamma_{1} \ln \left(\mathrm{Z}_{1 \mathrm{it}}\right)+\gamma_{2} \ln \left(\mathrm{Z}_{2 \mathrm{it}}\right)+\gamma_{3} \ln \left(\mathrm{Z}_{3 \mathrm{it}}\right)+\varepsilon_{\mathrm{it}}$

Where $\mathrm{i}=1,2, \ldots, \mathrm{N}$ refers to cross-sectional units, hereafter referred to as countries, and $\mathrm{t}=1,2, \ldots, \mathrm{T}$ refers to a given time period. Thus $Y_{i t}$ is the value of a dependent variable (foreign direct investment) for a country $i$ at time $t$, and $X_{\text {kit }}$ (and $Z_{\text {kit }}$ ) is the value of the k-th explanatory variable for country $i$ at time t. The $\beta_{\text {kit }}$ and $\gamma_{\text {kit }}$ are unknown response coefficients of variation in Y for changes in X's and Z's independent variables. Dependent and independent variables are in the natural logarithm. The equation (1) estimates the elasticities of FDI with respect to GDP (gross domestic production), inflation rate, exchange rate fluctuations, the level of openness of the economy to international market, political stability index, and civil liberties index.

The independent variables are as listed:

$\mathrm{X}_{1 \mathrm{it}}=$ country's Gross Domestic Product, measured in thousands of dollars, $\mathrm{X}_{2 \mathrm{it}}=$ inflation rate level, $\mathrm{X}_{3 \mathrm{it}}=$ exchange rate in transition country against U. S. dollar, $Z_{1 i t}=$ openness index (it is calculated as a ratio of total trade (exports plus imports) to GDP), $Z_{2 \text { it }}=$ political stability index for each country over time (this index is in the scale from 1 (when political rights are high) to 7 (the least political stability)), $Z_{3 i t}=$ civil liberties indexes, also varies from 1(the highest level) to 7 (the lowest level of civil liberties in the country).

The model presented here does not intend to capture every single determinant of FDI in transition economies as suggested by other theories that have been developed up to this point. However, the case that institutions and economic policies heavily influence FDI has been made and it will be evaluated empirically. We will use political stability index and civil rights index as measures that can capture the institutional reform and progress. The variation on the inflation rate and exchange rate will be used for economic policy variables. 
We run a regression employing pooled cross-sectional data described above using EVIEWS. We assume that the intercept is nonrandom and varies across countries. Slope coefficients are constant across countries and across time. Given the fact that countries are different in size (fact that will be reflected in different magnitudes of data on independent and dependent variables) heteroscedasticity across sections is present (meaning that the error term is correlated within sections).

To correct for cross sectional heteroscedasticity, contemporaneous correlation, and unbalanced panel data we use the Seemingly Unrelated Regression Model (SURE), which is becoming a popular method of estimation when such problems exist (Baltagi, 2001).

\section{Countries Chosen}

This study will be limited to ten transition economies: Albania, Bulgaria, Croatia, Czech Republic, Hungary, Macedonia (FYR), Poland, Romania, Slovak Republic, and Slovenia. There are at least two reasons for this selection. The first reason is the commonality in space; they are geographically similar. Despite the cited similarities, Central and Eastern European countries vary greatly with respect to the economic conditions prevailing at the time of transition as well as the approaches they took with respect to transition. Since our interest is over the transition years, twelve-years-time-series of all variables for a given country will be used.

Data has been taken from the World Development Indicators published in 2003 by the World Bank (GDP, FDI inflow, inflation rate, total trade to GDP for openness index, and exchange rate) and Nations in Transit published every year from Freedom House (indexes for political stability and civil liberties progress ${ }^{2}$ ). Data used are for a period of twelve years, from 1990-2001. The size of the sample is 120 observations potentially, however due to some missing observations the panel data is unbalanced (and the number of observations used for the regression will be 98$)$.

\section{Hypotheses}

A number of hypotheses will be tested for two purposes. Testing will be for the purpose of accepting or rejecting the institutional progress and economic policy integrated model, and to draw conclusions about the policies that countries can undertake to enhance institutions and the level development by increasing the amount of foreign direct capital that flows in these countries. Hypothesis regarding the effect of market size, inflation rate, exchange rate fluctuations, openness of the economy to the international market, political stability, and civil liberties on FDI inflow will be tested to increase the understanding of their impact on the FDI inflows in these countries.

H1: FDI varies directly with political stability and political rights. An improvement in political rights indirectly creates a welcoming atmosphere for international businesses by lowering the level of uncertainty. Reforms and policies can become more predictable from a business point of view. This relationship is derived from the institutional path-dependence evolution model as described earlier. Countries have an adaptation function that is specific depending on the countries' reforms and level of development before the transition period. A flatter curve for this function means that the country can easily adopt new institutions and create a welcoming atmosphere for FDI flowing into the country.

Data on political stability for transitional economies shows that there is a positive relationship between progress in political stability and FDI inflows into the country. FDI varies directly with economic stability in a country. This variable will be designed to capture all the economic reforms including the development of property rights, privatization progress, and others. This hypothesis is different compared to the first one as it tries to explain difference in FDI by variations in the economic environments.

\footnotetext{
${ }^{2}$ We use these indexes for two reasons. One is because they are available to the public, therefore in the public domain. Secondly, because they are free of charge.
} 
What is the relationship between FDI flows and privatization in the country? The expectations would be that there is a positive relationship if privatization was opened to foreigners. If foreigners were not allowed to participate in direct privatization of state owned assets then it may be the case that there is a lagged positive relationship between FDI flow and privatization. This can be explained by the possibility of the domestic buyers willing to sell privatized assets to foreigners. The privatization index will be composed as a percentage of GDP privatized in a given year for a given country.

H2: FDI will vary inversely with inflation. Inflation can be seen as a negative sign for multinational that wants to invest in a country for at least two reasons. The first reason has to do with returns on invested capital that varies inversely with inflation in the economy. An increase in the inflation rate, for example, will decrease the real returns on the FDI inflow. Rate of return is a primary concern of businesses if it wanted to locate their production abroad. The other reason is that inflation signals foreign investors that the country's policy is "out of hand." High inflation means that a government's policies and a central bank's monetary policy are not satisfactory, and therefore the FDI inflow will decrease as inflation increases.

H3: FDI inflow varies directly with exchange rate fluctuations (the exchange rate here is defined as a ratio of Local Currency Units to U. S. dollar). This is assumed to happen for the same reasons as those for inflation. A two-fold effect will cause such relationship between exchange rate and FDI inflow. First, a stable exchange rate will signal investors that the government policies are working and the country's economy is not shocked by any policy variable that will effect their investment and returns. In an economic environment with small exchange rate fluctuations, returns on the investment expressed in dollars will be safer. Second, an increase in the exchange rate (causing local currency devaluation) will decrease the initial cost of FDI inflow (it takes less dollars to acquire the same amount of capital in this particular country).

H4: FDI varies directly with the level of country's openness. The level of openness is a determining factor on the FDI inflow. Openness index, measured as a percentage of trade to GDP, is a policy variable affected by the institutional development in the country and in the analysis it is considered as such (however, it has been denoted by (Z) in the model expressed by equation (1)). This is the first necessary condition for FDI to flow into a country. The less restrictive policy is on international trade (and capital movement), the more FDI flows in a country. Foreign firms (multinationals and/or FDI) will find it easy to export it products abroad if there are less restrictions on the export of goods. Less restriction on the imported goods means that the cost of moving part of the capital from the home country to a host country will be lower. This process is cumulative as the general economic environment becomes more promising for "followers."

\section{DISCUSSION OF THE RESULTS AND CONCLUSION}

This section presents the results of regression analysis, main findings and discuses them. It also contrasts empirical analysis results with hypotheses stated earlier in this paper. SURE model of pooled cross section data is estimated to obtain intercepts (different for each country) and slope ( $\beta$ and $\gamma$ ) coefficients. Table 1 show the descriptive statistics of data (variables) used in regression analysis.

FDI and GDP are both measured in millions of U. S. dollars. The civil liberties index and political stability ${ }^{3}$ index are a measurement of a county's performance on institutional advancement to market economy. They vary from 1 (the best performance level) to 7 (the worst performance). This is to be considered when coefficients are presented and discussed as the negative sign on the respective coefficients for political rights and civil liberties means a positive relation between these indexes and FDI inflow.

\footnotetext{
${ }^{3}$ Political process examines national executive and legislative elections, the development of multiparty systems, and popular participation in the political process. Civil liberties assess the growth of nongovernmental organizations, their organizational capacity and financial sustainability, and the legal and political environment in which they function; the development of free trade unions; and interest group participation in the policy process.
} 
Table 1: Descriptive Statistics of the Variables Used in the Models

\begin{tabular}{|l|c|c|c|c|c|c|c|}
\hline & $\begin{array}{c}\text { FDI } \\
\text { (in millions } \\
\text { of dollars) }\end{array}$ & $\begin{array}{c}\text { GDP } \\
\text { (in millions } \\
\text { of dollars) }\end{array}$ & $\begin{array}{c}\text { CL } \\
\text { (index } \\
\text { ranging } \\
\text { 1 to 7) }\end{array}$ & $\begin{array}{c}\text { ER } \\
\text { (exchange } \\
\text { rate) }\end{array}$ & $\begin{array}{c}\text { INF } \\
\text { (percentage } \\
\text { annually) }\end{array}$ & $\begin{array}{c}\text { PR } \\
\text { (index } \\
\text { ranging } \\
\text { 1 to 7) }\end{array}$ & $\begin{array}{c}\text { OPN } \\
\text { (in \%) }\end{array}$ \\
\hline Mean & 121.6086 & 3231.055 & 2.92 & 0.38 & 62.28 & 2.46 & 90.19 \\
\hline Sum & 12160.86 & 323105.5 & 292.00 & 38.34 & 6227.81 & 246.00 & 9019.35 \\
\hline Maximum & 934.1000 & 17625.62 & 7.00 & 0.75 & 1466.78 & 7.00 & 157.78 \\
\hline Minimum & 0.000000 & 70.97600 & 2.00 & 0.11 & -1.19 & 1.00 & 39.14 \\
\hline Std. Dev. & 181.5308 & 3673.3768 & 1.11 & 0.14 & 178.40 & 1.43 & 28.78 \\
\hline Observations & 100 & 100 & 100 & 100 & 100 & 100 & 100 \\
\hline
\end{tabular}

Exchange rate is in real terms expressed in local currencies one needs to buy the same amounts of goods and services in the domestic market as the dollar would buy in U. S. A. Inflation is given as an annual percentage calculated using GDP deflator. The openness index represents the percentage of GDP exported and imported (traded with the rest of the world). Equation (1) is estimated using a double log econometric model with the SURE technique. All coefficients have the expected signs and the adjusted $\mathrm{R}^{2}$ is relatively high (it suggests that 80 percent of variation in FDI inflow is explained by the independent variables in the model). A report of the estimated coefficients is presented in Tables 2 and 3.

Table 2: SURE Estimation of Determinants of FDI, Equation (1) with GDP Included

\begin{tabular}{|c|c|c|}
\hline Variable & Coefficient & Std. Error \\
\hline LOG(GDP) & 0.093854 & 0.289392 \\
\hline LOG(OPN) & 1.860754 & 0.258696 \\
\hline LOG(PR) & -0.802942 & 0.158865 \\
\hline LOG(CL) & -0.674568 & 0.239965 \\
\hline LOG(INF) & -0.177878 & 0.058999 \\
\hline LOG(ER) & 0.716058 & 0.221357 \\
\hline R-squared & \multicolumn{2}{|c|}{0.834686} \\
\hline Adjusted R-squared & \multicolumn{2}{|c|}{0.804446} \\
\hline Number of observations & \multicolumn{2}{c}{} \\
\hline
\end{tabular}

From the coefficients of the independent variables, only GDP (a proxy for the size of the market variable) is statistically insignificant. All other coefficients are statistically significant as statistical t's are higher than the critical value of 2.66 (there are 92 degrees of freedom after we subtract number of variables from the total number of observations). For this reason, another regression is run excluding GDP as an independent variable.

\footnotetext{
${ }^{4}$ The real effective exchange rate is given by the nominal exchange rate (ration of LCU per dollar) multiplied by the price ratio. This is measured by the purchasing power parity conversion factor. It is the number of units of a country's currency required to buy the same amount of goods and services in the domestic market as a U.S. dollar would buy in the United States.
} 
Table 3: SURE Estimation of Determinants of FDI, Equation (1) with GDP Excluded

\begin{tabular}{|c|c|c|}
\hline Variable & Coefficient & Std. Error \\
\hline LOG(OPN) & 1.841944 & 0.256213 \\
\hline LOG(PR) & -0.834605 & 0.132046 \\
\hline LOG(CL) & -0.654351 & 0.217038 \\
\hline LOG(INF & -0.224497 & 0.035758 \\
\hline LOG(ER) & 0.547402 & 0.209790 \\
\hline R-squared & & 0.836617 \\
\hline Adjusted R-squared & \multicolumn{2}{|c|}{0.809058} \\
\hline Number of observations & 98 \\
\hline
\end{tabular}

Next, a discussion of these coefficients is presented. Since a double logarithmic econometric model is used, all coefficients on the independent variables represent elasticities (they show the percentage change on FDI inflow for a percentage change on the independent variable). Let us denote elasticities with E. For example, elasticity of FDI inflow with respect to GDP (given as a percentage change in FDI inflow for a percentage change in the GDP) will be given as follows:

$\mathrm{E}_{\mathrm{Y}, \mathrm{X}_{1}}=\beta_{1}=\frac{\mathrm{Y}}{\mathrm{X}_{1}} \frac{\Delta \mathrm{X}_{1}}{\Delta \mathrm{Y}}$.

Analogously, all other $\beta$ 's estimated using equation (1) represent respective elasticities of FDI with respect to X's and Z's variables.

Let us first discuss the effect of the size of the market on the FDI inflow. From the regression analysis, the coefficient representing GDP effect on the FDI inflow is not statistically significant. The economic significance is questionable from the estimation point of view (its coefficient relative size is small compare with other variables in the model). Why is this case? Size of the market should affect FDI inflow; however, in this case FDI inflow is peculiar in the sense that most of it is in the form of change of ownership of the country's assets.

It is difficult to obtain data represented as a percentage of FDI due to privatization. The World Investment Report (2001) emphasizes this (FDI through privatization) as a key factor that might have decreased the importance of the size of the market effect. The conclusion from the data available is that FDI inflow in countries in Central and Eastern Europe are neither market seeking nor resource seeking.

Another regression without GDP as a measure of the size of the market is run and presented in Table 2. The result is not different than the regressions with GDP included, leading to the conclusion that the model is not misspecified. One possibility is that the coefficient of openness, which is relatively large (1.86) might have captured the size of the market effect.

The openness coefficient shows that policies and institutions that attract FDI would be those that have liberalized the FDI inflow restrictions as measured by percentage of total trade to GDP. That is, the higher the level of exports and imports in the country, the greater the FDI inflows. The volume of trade is related, among other things, to the favorable regime of taxes and tariffs that country has adopted. This policy aims to increase foreign direct investment and improve the social conditions in the country.

FDI elasticity with respect to openness is 1.86 . That means that a one percent increase in the openness has caused 1.86 percent increase in the FDI inflow. As an example, if openness index increased from 90 to 92 percent (2.2 percent) the FDI inflow will increase by $(1.86 \times 2.2$ percent or 4 percent $) 4$ percent or in absolute terms, it will increase from 120 million to 125 million (by 5 million U. S. dollars). 
Next, we analyze the results of estimation with respect to institutional progress in transition economies. Political stability and civil liberties have a significant impact on the FDI inflow. As shown in the Table II.5, FDI elasticity with respect to these variables is relatively large (FDI elasticity with respect to political stability is 0.80 and the FDI elasticity with respect to civil liberties index is 0.67 ). The negative sign is due to the way indexes have been measured (an increase in the index shows that political stability and civil liberties has worsened).

As an illustration, suppose that political stability index changed from 2.8 to 2.5 showing a progress towards more stability in the country. This is approximately a 10 percent improvement in the political stability index. This will cause FDI inflow to increase by 8 percent $(0.8 \times 10$ or 8 percent) or FDI will change from 120 million U. S. dollars to 129.6 million (an absolute increase by 9.6 million dollars). The same progress in the civil liberties (an improvement of civil environment from 2.8 to 2.5, for example) will increase the flow of FDI by 6.7 percent or by 8 million dollars.

Foreign firms view political stability and civil liberties as factors that lower the uncertainty of their business and profits. In addition, a stable country may have settled official and unofficial rules (formal and informal institutions) to favor and welcome foreign investors. A positive attitude towards foreign investment is very attractive for foreign firms to consider when actually moving into the country. The empirical results reveal that FDI inflow is affected more by the political stability as compared with civil liberties.

Inflation is a significant factor determining the level of FDI (FDI elasticity with respect to inflation rate is 0.17). All that we can say about inflation's impact on FDI inflows is that inflation when under control (kept at a lower level) attracts more FDI in the country and in the region. In addition, a low inflation rate signals investors that the monetary policy is being handled properly and the real returns from investing in these countries will be closely matching investor expectations.

With respect to the effect of the exchange rate variability in the FDI flow, the estimated elasticity is statistically significant and is relatively large (FDI elasticity with respect to changes in the real exchange rate is 0.7). Findings are consistent with and supportive of the hypothesis stated earlier and show that foreign firms see exchange rate as a factor that affects their purchasing power. A real depreciation of domestic currency by one percent will increase FDI inflow by 0.7 percent.

Several policy implications can be drawn from these results. First, policy lessons for these countries and their respective governments are to strengthen the institutions that determine both political stability and civil liberties and also formulate and carry out sound economic policies. Applying and monitoring well-formulated economic and social policies would attract more foreign direct investment in these countries. Another very important lesson is that countries should liberalize their export and import regimes. These will affect both exports, imports, i.e. the total trade and will increase the level of FDI inflow.

This study is limited by the time. Contributions include an effort to formalize and expand the understanding of development of institutions in the transition economies, linking it with FDI flows, and generating results that show not only the effects that these institutions have on FDI but also show the way policy can be formulated.

Agim Kukeli is Assistant Professor of Economics, Department of Business Administration, Mesa State College, Grand Junction, Colorado. Corresponding address: Mesa State College, Department of Business, 1100 North Avenue, Grand Junction, CO. Corresponding E-mail: akukeli@mesastate.edu.

\section{REFERENCES}

1. Antaloczy, K. and M. Sass, Greenfield Investment in Hungary: Are they Different from Privatization FDI?, Transnational Corporation, No. 3 (December), 2001.

2. $\quad$ Baltagi, B. H., Econometric Analysis of Panel Data, John Wiley \& Sons, 2001.

3. Buckley, A., Multinational Finance, 1996, Prentice Hall, London. 
4. Cantwell, J. A., Technological Innovation and Multinational Corporation, Oxford, Basil Blackwell, 1989.

5. $\quad$ Coase, R. H., The Nature of the Firm, Economica, 4, 1937.

6. Dielman, T., Pooled Cross-Sectional and Time Series Data Analysis, Marcel Dekker, Inc., New York, 1989

7. Dunning, J. and A. Rugman, The Influence of Hymer's Dissertation on the Theory of Foreign Direct Investment, American Economic Review, 75 (May), 1985.

8. $\quad$ Dunning, J., Multinationals, Technology and Competitiveness, London: Unwin Hyman, 1988.

9. Dunning, J., Trade Location of Economic Activity and the Multinational Enterprise: A Search for an Eclectic Approach, in B. Ohlin, P. O. Hesselborn and P. M. Wijkman (eds.), The International Allocation of Economic Activity, Macmillan, London, 1977.

10. Fabry, N., "The Role of Inward-FDI in the Transition Countries of Europe: An Analytical Framework," in B. Kogut Transition in Asia and Eastern and Central: A Closed Door Two Open Windows?, Nova Science Publishers, Huntington, NY, 2001.

11. Fan, C. M. and L. S. Fan, Institutional Design for Emerging Economies, International Review of Economics and Business, Vol. L, No. 2, June 2003, pp. 145-161.

12. Freedom House, Nations in Transit, 1998.

13. _ Nations in Transit, 2002.

14. Gujarati, D., Basic Econometrics, Fourth Edition, McGraw-Hill, New York, 2003.

15. Hymer, S. H., The International Operations of National Firms: A Study of Direct Foreign Investment, 1960, MIT Press, Cambridge, MA.

16. Kindlerberger, C. P., American Business Abroad: Six Lectures on Direct Investment, 1969, Yale University Press, New Haven, CT.

17. Nigh, D., Political Events and the Foreign Direct Investment Decision: an Empirical Examination, Managerial and Decision Economics, vol. 7, 1986.

18. North, D., Institutions, Institutional Change and Economic Performance, Cambridge University Press, 1990.

19. Rugman, A. M., New Theories of the Multinational Enterprise: An Assessment of Internalization Theory, Bulletin of Economic Research, 39 (2), 1986

20. Szanyi, M., Privatization and Greenfield FDI in the Economic Restructuring of Hungary, Transnational Corporation, 3 (December), 2001.

21. Vernon, R., International Investment and International Trade in the Product Cycle, Quarterly Journal of Economics, 80 (May), 1966.

22. Williamson, O., The Economic Institutions of Capitalism, New York: Free Press, 1985.

23. World Development Indicators 2003, World Bank, Washington D. C.

24. World Economic Outlook, October 2000, IMF, Washington D. C.

25. Zeghni, S., Risk in Transition Economies: The Impact of Host Country Characteristics on FDI Determinates, in B. Kogut Transition in Asia and Eastern and Central: A Closed Door Two Open Windows?, Nova Science Publishers, Huntington, NY, 2001. 
